\title{
Interchangeability of genotypes and growth locations for high-quality, high-protein wheat production in Australia
}

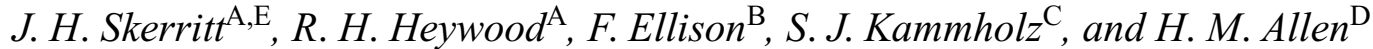 \\ ${ }^{A}$ CSIRO Plant Industry and Quality Wheat CRC Ltd, Canberra, ACT 2601, Australia. \\ ${ }^{\mathrm{B}}$ Deceased. Formerly: Plant Breeding Institute, Sydney University, Narrabri, NSW 2390, Australia. \\ ${ }^{\mathrm{C}}$ Leslie Research Centre, Queensland Primary Industries, Toowoomba, Qld 4350, Australia. \\ ${ }^{D}$ NSW Agriculture, Wagga Wagga Agricultural Institute, Wagga Wagga, NSW 2650, Australia. \\ ${ }^{\mathrm{E}}$ Corresponding author; current address: Australian Centre for International Agricultural Research, GPO Box 1571, \\ Canberra, ACT 2601, Australia; email: skerritt@aciar.gov.au
}

\begin{abstract}
The aim of this study was to assess whether the recent finding that 4 Prime Hard wheat varieties grown at southern sites provided flour of comparable quality to that from northern sites is likely to be generally applicable to other varieties, as this is especially important as new varieties are developed. The grain, dough processing, and baking properties of samples from 4 sets of lines, each grown over 2 seasons at 2 northern and 2 southern sites, was assessed. The samples included 2 sets of doubled haploid lines (one derived from Hartog $\times$ Klasic, differing only at Glu-A3, and the other Hartog $\times$ CD-87, differing at 5 glutenin loci), and 2 sets of $\mathrm{F}_{8}$ crossbred lines (from Janz/Hartog and Janz*2/Dollarbird, permitting an additional comparison of effects of allelic variation at the Glu-D1 locus). Approximately similar grain protein contents were obtained at one pair of northern and southern sites (respectively Narrabri and Ariah Park, 12-14\%) and a second pair of northern and southern sites (respectively Roma and Walpeup, 14-17\%, although the latter was consistently higher). The results demonstrated that the grain, dough, and baking properties of the lines were broadly similar at each protein content, and that in general, grain from the southern sites had comparable quality characteristics to that from the northern sites. However, in 1997, the Walpeup southern site suffered very dry conditions late in grain filling, and several of the grain samples were of low size and poor flour milling extraction rate and colour. In 1998, wet conditions late in the season meant that the grain at Ariah Park was lower in protein content and doughs were of lower extensibility and produced depressed loaf volumes. The variation in glutenin subunit composition also permitted the conduct of a detailed comparison of allelic influences on flour processing and baking properties at 4 sites and in 4 backgrounds. This revealed significant effects of allelic variation at $G l u-B 1, G l u-D 1$, and $G l u-B 3$ on dough properties, with the effect of $G l u-B 1$ differing between sets of lines.
\end{abstract}

Additional keywords: Triticum aestivum L., grain protein content, top-dressing.

\begin{abstract}
Introduction
Wheat received in the 'Australian Prime Hard' (APH) grade is the highest premium-paying hexaploid wheat category and has specific quality requirements. Such varieties must be classified as having prime hard quality, grain protein content must exceed $13 \%$, and grain must have test weight greater than $75 \mathrm{~kg} / \mathrm{hL}$ and have low screenings $(<5 \%)$ and Falling Number $>350 \mathrm{~s}$. Wheat classified in APH grade has high dough extensibility and strength and high milling yield. Receival of APH wheat has traditionally been limited to Queensland and northern New South Wales (north of Condobolin, NSW). However, the high frequency of either drought or weather damage in these summer-rainfall areas, and the concern about continuity of supply to markets, have
\end{abstract}

led industry to assess the potential of other areas to grow APH wheat. Growers outside the traditional receival areas for APH wheat have felt that they have been unnecessarily prevented from receiving APH premiums when delivering grain of the 'correct' variety and protein level. Protein levels $>13 \%$ have often been achieved in drier grain-growing areas in southern Australia on relatively fertile soils in seasons of low to average rainfall. In addition, late nitrogen top-dressing before rain has been shown by Oliver et al. $(1996,1997)$ to reliably produce high protein at more southern and eastern sites.

One of the main issues that require addressing is whether $\mathrm{APH}$ varieties maintained the required quality when grown in southern Australia. A number of Australian research 
organisations undertook a project in which 4 commercial APH varieties were sown at 11 (1995), then 17 (1996) and 18 (1997) sites, including control sites and test sites in NSW, Victoria, Queensland, and Western Australia. Milling and dough tests of flour from wheat that achieved over 13\% protein (from the 1995 and 1996 harvests) and 15\% protein (1995 harvest) suggested that southern sites were similar in quality to northern sites. The exception to this was that flour extraction rates for many of the 1995-13\% set and some of the $1995-15 \%$ set were below the grade standard value. A similar result was seen in 1996, although several of the northern controls were also depressed (Oliver et al. 1996, 1997; Allen et al. 1998; Allen and Pumpa 1999). In the 1997 harvest, 5 silos in southern New South Wales received grain of 'Southern Australian Prime Hard' grade; in 4 cases, this was the first time they had done so. However, seasonal conditions meant that the grain had lower milling extraction than Northern Prime Hard. It also had a different varietal mix complicating the interpretation of any comparisons. In subsequent seasons, there have been further receivals of wheat into this grade from southern areas, and the customers have reported acceptable quality characteristics. However, a scientific comparison of the quality characteristics of the grain from southern and northern sites in these seasons was hard to carry out, since the grain from southern and northern sites was of a different varietal mix, and in different seasons there were the complicating effects of drought, wet seasons, and frost on the quality of the grain. Recent research in several countries has shown that high grain protein levels can be obtained from application of nitrogenous fertiliser late in the cropping season (Woodard and Bly 1998; Bhandari 2000).

Our project addresses through a more detailed genetic study, whether the lack of variation between northern and southern environments that was observed for a small number of varieties is a more generally applicable finding. This is important since the rate of development and release of new APH varieties is high (www.awb.com.au). In addition, the study provided additional information on the relationship between glutenin allelic composition and dough properties in wheat of closely matched protein content and quality type grown at 4 different environments.

\section{Materials and methods}

\section{Wheat lines}

Doubled haploid lines in white hard-grained strong-doughed wheat were developed by P. Brennan and S. Kammholz (formerly of the Leslie Research Centre, Toowoomba, Qld, Australia). The 2 populations assessed were derived from a cross between the varieties Hartog $\left(\mathrm{HM}_{\mathrm{r}} \mathrm{GS} 1,17+18,5+10\right.$ (a i d), $\mathrm{LM}_{\mathrm{r}} \mathrm{GS}$ b h e) and Klasic $\left(\mathrm{HM}_{\mathrm{r}} \mathrm{GS} 1\right.$, $17+18,5+10(\mathrm{a} \mathrm{i} \mathrm{d}), \mathrm{LM}_{\mathrm{r}} \mathrm{GS} \mathrm{d} \mathrm{h}$ e), thus differing at only one gliadin/glutenin locus, Glu-A3, and Hartog $\times$ CD87 $\left(\mathrm{HM}_{\mathrm{r}} \mathrm{GS} 2,7+8\right.$, $2+12(\mathrm{~b} \mathrm{~b}$ a), LM GS b b a), thus differing at 5 of 6 Glu-1 and Glu-3 loci. Two populations of crossbred lines were also studied. In the first, 36 lines were selected from $182 \mathrm{~F}_{8}$ lines derived from a cross between the Australian Prime Hard varieties Hartog and Janz $\left(\operatorname{HM}_{\mathrm{r}} \mathrm{GS} 1,7+8\right.$, $2+12\left(\mathrm{a} b\right.$ a), $\mathrm{LM}_{\mathrm{r}} \mathrm{GS} \mathrm{b}$ b b), already selected for multiple rust resistance. They were selected on the basis of uniformity. We used the one-step SDS-PAGE method of Singh et al. (1988) for determination of glutenin compositions. Initially, small meal samples of 10 grains were prepared, after initially determining that with the high-sensitivity Coomassie Blue staining method of Neuhoff et al. (1988), we could detect as little as a $10 \%$ mixture of genotypes. Since the $95 \%$ confidence limits that there may be an undetected mixture within the material is still not insignificant (Wrigley and Baxter 1974), a meal of a further 10 grains was tested from the selected lines. About half of the lines were uniform. Of these, a subset of 36 was expanded at Narrabri in the 1997 season, and then sown at each of the 4 sites in 1998 and 1999. Apart from the 4 possible combinations at each of the $\mathrm{HM}_{\mathrm{r}}$ and $\mathrm{LM}_{\mathrm{r}} \mathrm{GS}$ loci, some lines were identified that were null for the Glu-A1 subunit. The second population of lines was derived from a Janz*2/Dollarbird [an Australian Hard variety, $\mathrm{HM}_{\mathrm{r}} \mathrm{GS}(1,17+18,5+10$ or a i d)] and $\mathrm{LM}_{\mathrm{r}} \mathrm{GS}$ ( $\mathrm{b} \mathrm{h}$ b) cross. Dollarbird thus differed from Janz at $2 \mathrm{HM}_{\mathrm{r}} \mathrm{GS}$ and one $\mathrm{LM}_{\mathrm{r}} \mathrm{GS}$ loci. However, to simplify the analysis, only crossbred lines with the bbb $\mathrm{LM}_{\mathrm{r}} \mathrm{GS}$ composition were analysed.

\section{Site characteristics}

Two northern sites, Roma (southern Queensland, 26 $32^{\prime} \mathrm{S}, 148^{\circ} 46^{\prime} \mathrm{E}$, $315 \mathrm{~m}$ a.s.1.) and Narrabri (northern NSW, 30 $0^{\circ} 19^{\prime} \mathrm{S}, 149^{\circ} 44^{\prime} \mathrm{E}, 212 \mathrm{~m}$ a.s.1.), and 2 southern sites, Ariah Park (southern NSW, $34^{\circ} 20^{\prime} \mathrm{S}$, $147^{\circ} 13^{\prime} \mathrm{E}, 249 \mathrm{~m}$ a.s.1.) and Walpeup (Victorian Mallee, $35^{\circ} 07^{\prime} \mathrm{S}$, $142^{\circ} 00^{\prime} \mathrm{E}, 107 \mathrm{~m}$ a.s.1.), were used. Mean temperatures and rainfall at each site during the seasons studied are shown in Table 1.

\section{Grain physical testing and wholemeal SDS-sedimentation testing}

Grain was threshed from individual samples using a Walter-Wintersteiger thresher (Reid, Austria), and hectolitre weight (subsamples of $100 \mathrm{~mL}$ were weighed) and 1000-kernel weight (subsamples of 200 kernels were weighed) were measured. Protein concentration was measured on the whole grain samples using near infrared (NIR) reflectance spectroscopy with a Bran + Luebbe Infraalyzer 260WG. Protein contents were corrected to that at $12 \%$ moisture. Subsamples $(50 \mathrm{~g})$ were ground into wholemeal using a Udy cyclone mill (Udy, Fort Collins, CO) for analyses of SDS-sedimentation volume (SDS-SV). This test, which is widely regarded as a predictive measure of the loaf volume, was performed as described by Pena et al. (1990). Wholemeal (1 g) was weighed into a $25-\mathrm{mL}$ glass measuring cylinder, and $6 \mathrm{~mL}$ of $0.001 \%(\mathrm{w} / \mathrm{v})$ bromophenol blue in water was added. After mixing for $5 \mathrm{~s}$ on a vortex mixer, the suspension was stood for $5 \mathrm{~min}$ with intermediate vortex mixing at 2.75 and $4.75 \mathrm{~min} ; 19 \mathrm{~mL}$ of a $2 \%(\mathrm{w} / \mathrm{v})$ SDS $-2.9 \%(\mathrm{w} / \mathrm{v})$ lactic acid mixture was added, the cylinders capped and placed horizontally in an empty shaking water bath, and shaken at 40 cycles/min for $5 \mathrm{~min}$. They were removed and placed vertically. After standing for $14 \mathrm{~min}$, the volume of the sediment was measured.

\section{Milling analyses and flour colour}

Wheat ( $3 \mathrm{~kg}$ ) was conditioned to $14.6 \%$ moisture level for $24 \mathrm{~h}$. An extra $0.4 \%$ moisture was added $0.5 \mathrm{~h}$ before milling. Each sample was milled with a Buhler MLU202 test mill (Buhler-Miag, Uzwil, Switzerland). Flour extraction was calculated as a percentage of the total recovered products. A Minolta Chroma meter model CR-200 was used to measure flour colour as L*, a*, b* (Oliver et al. 1992 ).

\section{Physical dough tests}

A Brabender Farinograph was used to measure water absorption (FWA), dough development time (DDT), dough stability, and breakdown at $5 \mathrm{~min}$, using the Farinograph reference method (Royal 
Table 1. Mean temperatures and rainfall during the growing season at each site

\begin{tabular}{|c|c|c|c|c|c|c|c|c|c|c|}
\hline \multirow{2}{*}{$\begin{array}{l}\text { Site and } \\
\text { season }\end{array}$} & \multirow[t]{2}{*}{ May } & \multirow[t]{2}{*}{ June } & \multirow[t]{2}{*}{ July } & \multirow[t]{2}{*}{ Aug. } & \multirow[t]{2}{*}{ Sept. } & \multirow[t]{2}{*}{ Oct. } & \multirow[t]{2}{*}{ Nov. } & \multirow{2}{*}{$\begin{array}{c}\text { Temp. } \\
\text { May-Nov. av. }\end{array}$} & \multicolumn{2}{|c|}{ Rainfall totals } \\
\hline & & & & & & & & & Season & Annual \\
\hline \multicolumn{11}{|c|}{ Temperature $\left({ }^{\circ} \mathrm{C}\right)$} \\
\hline \multicolumn{11}{|l|}{ Roma } \\
\hline 1997 & 13.0 & 14.0 & 13.5 & 17.5 & 18.7 & 21.6 & 25.2 & 17.6 & & \\
\hline 1998 & 15.7 & 16.8 & 12.8 & 14.7 & 18.1 & 20.5 & 22.6 & 17.3 & & \\
\hline 1999 & 16.8 & 12.6 & 12.2 & 13.5 & 18.3 & 23.0 & 21.3 & 16.8 & & \\
\hline Mean (86 years) & 16.2 & 12.8 & 11.9 & 13.8 & 17.5 & 21.7 & 24.7 & 16.9 & & \\
\hline \multicolumn{11}{|l|}{ Narrabri } \\
\hline 1997 & 16.2 & 12.6 & 11.7 & 12.5 & 16.8 & 20.2 & 25.9 & 16.6 & & \\
\hline 1998 & 15.4 & 12.5 & 11.4 & 14.3 & 17.6 & 19 & 21.2 & 15.9 & & \\
\hline 1999 & 17.1 & 12.8 & 12.9 & 13.9 & 17.3 & 16 & 20.1 & 15.7 & & \\
\hline Mean (38 years) & 15.4 & 11.9 & 10.8 & 12.3 & 15.4 & 19.4 & 22.5 & 15.4 & & \\
\hline \multicolumn{11}{|l|}{ Ariah Park } \\
\hline 1997 & 12.9 & 7.8 & 6.8 & 8.1 & 10.8 & 14.3 & 22.7 & 11.9 & & \\
\hline 1998 & 12.2 & 8.5 & 8.1 & 10.4 & 12.9 & 13.8 & 17.1 & 11.9 & & \\
\hline 1999 & 12.6 & 8.3 & 8.8 & 7.7 & 13.5 & 16.1 & 15.8 & 11.8 & & \\
\hline Mean (54 years) & 11.7 & 8.5 & 7.5 & 8.9 & 11.4 & 15 & 18.2 & 11.6 & & \\
\hline \multicolumn{11}{|l|}{ Walpeup } \\
\hline 1997 & 13.2 & 10.8 & 9 & 10.3 & 12.2 & 17 & 20.9 & 13.3 & & \\
\hline 1998 & 13.4 & 10.2 & 8.6 & 11.8 & 14.7 & 15.8 & 18.8 & 13.3 & & \\
\hline 1999 & 14.3 & 10.7 & 10.8 & 11.3 & 14.6 & 17.4 & 17.6 & 13.8 & & \\
\hline Mean (50 years) & 13 & 10.3 & 9.6 & 10.8 & 13.1 & 15.9 & 18.7 & 13.1 & & \\
\hline \multicolumn{11}{|c|}{ Rainfall (mm) } \\
\hline \multicolumn{11}{|l|}{ Roma } \\
\hline 1997 & 49 & 1 & 4 & 0 & 19 & 66 & 39 & & 179 & 543 \\
\hline 1998 & 33 & 29 & 50 & 82 & 65 & 47 & 98 & & 404 & 673 \\
\hline 1999 & 32 & 63 & 23 & 9 & 1 & 43 & 92 & & 262 & 741 \\
\hline Mean (120 years) & 38 & 35 & 37 & 27 & 32 & 51 & 54 & & 273 & 600 \\
\hline \multicolumn{11}{|l|}{ Narrabri } \\
\hline 1997 & 50 & 36 & 15 & 7 & 50 & 83 & 28 & & 269 & 744 \\
\hline 1998 & 64 & 67 & 155 & 83 & 142 & 83 & 74 & & 668 & 961 \\
\hline 1999 & 3 & 62 & 56 & 72 & 29 & 133 & 90 & & 445 & 800 \\
\hline Mean (120 years) & 51 & 48 & 45 & 41 & 41 & 53 & 58 & & 337 & 645 \\
\hline \multicolumn{11}{|l|}{ Ariah Park } \\
\hline 1997 & 46 & 58 & 20 & 43 & 53 & 31 & 16 & & 267 & 344 \\
\hline 1998 & 11 & 87 & 44 & 40 & 85 & 40 & 25 & & 332 & 472 \\
\hline 1999 & 27 & 35 & 36 & 52 & 40 & 108 & 42 & & 340 & 626 \\
\hline Mean (94 years) & 42 & 42 & 42 & 41 & 39 & 46 & 38 & & 291 & 475 \\
\hline \multicolumn{11}{|l|}{ Walpeup } \\
\hline 1997 & 17 & 15 & 11 & 40 & 55 & 28 & 32 & & 199 & 251 \\
\hline 1998 & 13 & 17 & 37 & 13 & 45 & 30 & 59 & & 213 & 302 \\
\hline 1999 & 37 & 36 & 31 & 44 & 6 & 17 & 50 & & 221 & 360 \\
\hline Mean (60 years) & 33 & 31 & 34 & 35 & 33 & 36 & 27 & & 229 & 342 \\
\hline
\end{tabular}

Australian Chemical Institute, Cereal Chemistry Division 1988). Extensograph height $(R \max )$ and extensibility were determined using an Extensograph (Royal Australian Chemical Institute, Cereal Chemistry Division 1988). For the probe test, flour (25 g), salt ( $0.5 \mathrm{~g})$, and warm $\left(27^{\circ} \mathrm{C} \pm 1{ }^{\circ} \mathrm{C}\right)$ water $(12.5 \mathrm{~mL})$ were mixed for 2 min in a Simon Minowpin mixer (England). Doughs were hand-rounded and rested for $15 \mathrm{~min}$ in a sealed container at $25^{\circ} \mathrm{C}$. The rested dough was sheeted through reduction bakery rolls at $17 \mathrm{rpm}$ using the following settings: 9.0, 4.8, 3.1, 2.2, and $1.3 \mathrm{~mm}$. Dough pieces were rested for $15 \mathrm{~min}$ to allow recovery, then covered in a $25^{\circ} \mathrm{C}$ cabinet. The dough sheet was placed on a baseplate of a TA-XT2 Texture Analyser (Stable Micro Systems, Surrey, England), the baseplate having a 16.4-mm hole and using a probe of $141-\mathrm{mm}$ length and $11-\mathrm{mm}$ diameter. The probe speed was $5 \mathrm{~mm} / \mathrm{s}$ and the total distance travelled was $95 \mathrm{~mm}$. The force $(\mathrm{g})$ gave a measure of dough strength and the distance $(\mathrm{mm})$ gave an indication of extensibility (modified from Oliver and Allen 1993).

Bake tests

The test baking formula used comprised: flour (110 g), yeast $(3.63 \mathrm{~g})$, sodium chloride $(2.2 \mathrm{~g})$, ammonium chloride $(0.11 \mathrm{~g})$, and malt extract $(0.63 \mathrm{~g})$. The amount of water to add was determined from the FWA. Doughs were mixed in a National pin mixer (National Manufacturing Co., Lincoln, NE, USA). After mixing, doughs were fermented for $1 \mathrm{~h}$ at $28^{\circ} \mathrm{C}$ in polyethylene screw-top containers, lightly hand-knocked, then were moulded through bakery rollers $(3.5-\mathrm{mm}$ gap setting, 17 rpm). They were then proved for $15 \mathrm{~min}$ at $28^{\circ} \mathrm{C}$, moulded in a Mono 
Universal moulder (Automatic Bakery Machinery, Swansea, England) at pressure 32 and gauge setting 1, and tin-proofed for $45 \mathrm{~min}$ at $33^{\circ} \mathrm{C}$ and $85 \%$ humidity. Loaves were baked in a Rotell II rotary oven model RBSR2D STD (APV Baker Pty Ltd) at $215^{\circ} \mathrm{C}$ for $20 \mathrm{~min}$. Loaf volume was determined using rapeseed displacement (National voltameter) and loaf scores were determined by American Association of Cereal Chemists Method 10-10.

\section{Testing strategy}

All samples of doubled haploid lines (98-101 of each set at each of 4 sites; Table 2) and all samples of cross-bred lines (50 in total at each of 4 sites; Table 2) were tested in each of 2 seasons for grain protein, hectolitre weight, 1000-kernel weight, and SDS-sedimentation volume. In 1998, a set of samples was grown in replicate plots, randomly distributed, at the Roma site. The 2 sets of Roma samples provided virtually identical yield, grain protein, grain characteristics, and SDS-sedimentation volume results (Table 2).

Approximately half of the doubled haploid lines (selected to maintain representative proportions of each glutenin allele combination) and all of the crossbred lines were submitted for milling. Milling and flour colour testing were performed on all samples, except for the Roma 1997 samples from the Hartog $\times$ CD87 population, which were unfortunately lost in transit by the courier between the collaborating laboratories. Farinograph, Extensograph, and baking tests were not performed on the high protein sites (Roma and Walpeup) in 1997 for both sets of doubled haploids and in 1998 for Hartog $\times$ Klasic. Instead, for both sites and both sets of lines and years, the modified probe test was performed (Table 5). The measures of force and distance in this test are analogous to Extensograph maximal resistance and extensibility, respectively. Milling, dough tests, and the baking tests were only performed with the crossbreds grown in 1998 (Table 6), and several of the physical dough and baking tests were not performed for the Walpeup site due to high grain protein content.

\section{Statistical methods}

We were interested in whether the grain (and resultant doughs) from northern sites was different from the southern sites at a given protein content. However, as the Walpeup site had a much higher protein content than Ariah Park and Narrabri in particular, it was obvious that there would be a significant latitude effect. Therefore, individual latitude contrasts were calculated for pairs of similar grain protein content, namely Narrabri $v$. Ariah Park (typically $11-13 \%$ grain protein content) and Roma $v$. Walpeup (typically $14-17 \%$ grain protein content). The data were analysed in GENSTAT (6th edn, Version 6.1,
VSN International Ltd, Hemel Hempstead, UK). The following 2 models were fitted to each response variable.

(1) To compare specific sites and specific years, sites or years were treated as fixed effects in the analysis. The fixed effect means (see Tables 3 and 5) are the actual means for that variety at that site and year. The analysis with year as a fixed effect gave estimates of differences between crosses for each contrast in each year.

(2) To generalise beyond the particular sites and/or particular years used in the experiment to make generalisations across a region and/or over time, sites and/or years were treated as random effects in the analysis. The random effect means (see Tables 4 and 6) are the predicted means for a particular variety at a particular site over all years. This can determine whether the contrast differences for each cross were consistent from year to year.

In the statistical model and analysis, fixed effects and random effects were treated differently because of the different inferences we wished to make, and hence means, predictions, and standard errors differ somewhat between the 2 types of analysis.

Varying numbers of lines of each cross were used in each experiment because of the availability of lines of pure genotype. The study took place over 3 years, 1997, 1998, and 1999, but each cross was grown for only 2 consecutive years. The milling analyses, physical dough tests, and bake tests were performed in 1997 and 1998. Thus the design was severely unbalanced, both with regard to the treatments and to the experimental units. Because of this, the order of fitting the effects affected their significance in the model. The interactions between cross and the contrasts were found to be statistically significant in almost every case. This means that the magnitude of the contrast difference varied from cross to cross; at least one of these differences was statistically significant. In the tables we present only the cross by contrast interactions. The difference between contrasts means for each cross can be compared using the standard error of a difference (s.e.d.). For brevity, only the average s.e.d.s are given in the tables. In the analysis with year as a fixed effect (see Tables 3 and 5), for simplicity we present only the $P$-values for the 3-way interaction. For the analysis with year as a random effect we give $P$-values for each 2 -way interaction when fitted last in the model (see Tables 4 and 6). As at least one of these interactions was significant in each analysis, the significance of the main effects is not interpretable.

The glutenin data (see Figs 1-3) are means and standard deviations of the data for individual genotypes at each site. Data on the glutenin subunit analysis were not combined across sites since the variation in grain protein contents between sites would significantly complicate any across-site analysis of the glutenin subunit effects.

Table 2. Comparison of grain properties and SDS-sedimentation of replicate sets of doubled haploid lines grown at Roma (1998 harvest)

Data shown are means \pm standard deviation

\begin{tabular}{lccccc}
\hline & $\begin{array}{c}\text { Grain } \\
\text { protein } \\
(\%)\end{array}$ & $\begin{array}{c}\text { Yield } \\
(\mathrm{t} / \mathrm{ha})\end{array}$ & $\begin{array}{c}\text { Hectolitre } \\
\text { weight } \\
(\mathrm{kg})\end{array}$ & $\begin{array}{c}\text { 1000-kernel } \\
\text { weight } \\
(\mathrm{g})\end{array}$ & $\begin{array}{c}\text { SDS-sed. } \\
\text { volume } \\
(\mathrm{mL})\end{array}$ \\
\hline \multicolumn{5}{c}{ Hartog $\times C D 87^{A}$} \\
Roma & $14.2 \pm 0.7$ & $3.6 \pm 0.6$ & $77.6 \pm 3.0$ & $36.4 \pm 9.0$ & $11.4 \pm 1.8$ \\
Roma (replicate) & $14.0 \pm 0.7$ & $3.5 \pm 0.6$ & $78.1 \pm 5.3$ & $36.7 \pm 7.9$ & $11.6 \pm 1.8$ \\
Roma & \multicolumn{7}{c}{ Hartog $\times$ Klasic $^{B}$} \\
Roma (replicate) & $13.8 \pm 0.7$ & $4.2 \pm 0.5$ & $77.7 \pm 2.6$ & $35.4 \pm 5.1$ & $12.1 \pm 1.0$ \\
\hline
\end{tabular}

A98 lines per site.

${ }^{\mathrm{B}} 101$ lines per site. 


\section{Results and discussion}

\section{Characteristics of sites, weather data, and anthesis dates}

The northern sites, which receive summer-dominant rainfall and under which the crop develops using stored water, have been the traditional growth areas of the APH varieties. The seasonal temperature data, as well as the long-term averages (Table 1), reveal significant differences between the 2 northern sites and the southern sites. Frosts are also common between June and August at Ariah Park and occur occasionally at Walpeup, but are rare at the 2 northern sites. Dates of sowing, anthesis, and harvesting for the 4 sites over the 3 seasons were as follows:

Roma-sowing (9-23 June), anthesis (5-17 September), harvest (25 October-3 November);

Narrabri-sowing (26 May-9 June), anthesis (23 September-9 October), harvest (18-30 November);

Ariah Park-sowing (15-22 May), anthesis (1-14 October), harvest (27 November-14 December);

Walpeup-sowing (21 May-20 June), anthesis (8-19 October), harvest (7-8 December).

This suggests that the actual temperature conditions (e.g. 'degree days') under which the crops mature are not as different as a superficial analysis of the average temperature data suggests. However, the length of the season is somewhat greater at the southern sites. The average annual rainfall at the sites differs significantly, with the 2 northern sites receiving somewhat higher amounts (Table 1). However, the average growing season rainfall (roughly calculated as May-November rainfall) shows less variation. There was marked season-to-season variation over the 3 years of the trial. The 1997 season was comparatively dry at all sites in the first half of the season, whereas the 1998 season was very wet at the 2 northern sites but more typical at the 2 southern sites. The 1999 season was dry around anthesis at Roma and Walpeup, but wet at this time at Roma and Ariah Park.

The soil at the Roma site was a heavy cracking brown clay, which was self-mulching. Fertiliser was applied just before sowing [1997, $120 \mathrm{~kg} / \mathrm{ha}$ of urea $(55 \mathrm{~kg} \mathrm{~N} / \mathrm{ha})$ plus $40 \mathrm{~kg} / \mathrm{ha}$ of Granulock Starter-Z (10\% N, 20\% P, 2.5\% S)]. Seeding rate was 100 seeds $/ \mathrm{m}^{2}$. The soil at Narrabri was a deep cracking, heavy textured black vertisol. Fertiliser was applied at sowing (1997, $50 \mathrm{~kg} \mathrm{~N} / \mathrm{ha}, 30 \mathrm{~kg} \mathrm{P} / \mathrm{ha} ; 1998,45 \mathrm{~kg}$ $\mathrm{N} / \mathrm{ha}, 25 \mathrm{~kg} \mathrm{P} / \mathrm{ha} ; 1999,50 \mathrm{~kg} \mathrm{~N} / \mathrm{ha}, 20 \mathrm{~kg} \mathrm{P} / \mathrm{ha})$. The plots were not top-dressed at either of the northern sites. The soil at Ariah Park was a red-brown sandy loam. Fertiliser was applied at sowing $(100 \mathrm{~kg} / \mathrm{ha}$ each year of Starter $15,14 \% \mathrm{~N}$, $11.5 \% \mathrm{P}, 10 \% \mathrm{~S}$ ) and $100 \mathrm{~kg} / \mathrm{ha}$ of urea was top-dressed each year after rains 1-2 weeks prior to the anthesis period. The soil at Walpeup is a dark reddish-brown sandy loam. Fertiliser was applied at sowing [1997, $50 \mathrm{~kg} / \mathrm{ha}$ urea plus $100 \mathrm{~kg} /$ ha double superphosphate $(17 \% \mathrm{P}, 4 \% \mathrm{~S}) ; 1998$, $50 \mathrm{~kg} /$ ha urea plus $100 \mathrm{~kg} /$ ha Pivot Technitrace $(16 \%$ N, 18\% $\mathrm{P}, 2.5 \% \mathrm{~K}$ with $2 \% \mathrm{Zn}$ ); $1999,50 \mathrm{~kg} /$ ha urea plus $100 \mathrm{~kg} / \mathrm{ha}$
Pivot Technitrace (16\% N, 18\% P, 2.5\% K with $0.2 \% \mathrm{Zn})]$. No top-dressing was used in the very dry 1997 season, but in 1998 and 1999, $50 \mathrm{~kg} / \mathrm{ha}$ urea was top-dressed after rains 1-2 weeks prior to anthesis. Table 1 shows the mean monthly rainfall and temperature, respectively, for the 4 locations in the growing seasons of the years the experiments were performed, together with the long-term annual means. Plot sizes depended on available land and the sowing and harvesting equipment used, and varied from 2 by $20 \mathrm{~m}$ (Narrabri) down to 1.4 by $12 \mathrm{~m}$ (Walpeup). Use of doubled haploid lines has the advantage of a fixed background, but there was a 2-3-week variation in maturity and up to $30 \mathrm{~cm}$ variation in plant heights for the Hartog $\times$ CD87 lines. The doubled haploid lines were also unselected for disease resistance, but there was comparatively little evidence of disease at any of the sites.

\section{Physical grain properties}

\section{Protein content}

In the 1997 harvest, only the DH lines were sown. Over $13 \%$ grain protein (the minimum desirable standard for Australian Prime Hard classification) was obtained at all sites for almost all lines, with one northern and one southern site (Narrabri and Ariah Park) each at $13-14 \%$ protein and Roma and Walpeup each at $15-17 \%$ grain protein (Table 3 ). Yields were higher and protein contents lower at the Narrabri site, as it was sprinkler-irrigated (twice each season to $40 \mathrm{~mm}$ prior to anthesis), whereas the Roma site was not irrigated. In the south, high protein was achieved at Ariah Park using late nitrogen application. At Walpeup, the lowest rainfall site, the first 3 months of the growing season (and the first 7 months of the year) were extremely dry, limiting yield (but increasing protein levels) through drought. Even though one of the sets of doubled haploid lines had exhibited some variation in maturity dates, the protein levels obtained at each site were relatively uniform. In the 1998 harvest, all sets of lines were grown. There were similar trends in the relative mean protein contents at the different sites, although mean protein contents were slightly lower (Tables 3, 4). The 1998 season was slightly wetter than 1997 at Ariah Park and Walpeup and was significantly wetter at the 2 northern sites; this would have had the effect of increasing the yield with a concomitant depression in protein content. Mean protein contents for some of the sets of lines fell just below 13\% (as low as $12.6 \%$ ) at Ariah Park (despite late $\mathrm{N}$ top-dressing) and Narrabri. Rainfall at Walpeup was again below average for the first 6 months of the year, so the high protein levels were again due to drought. In the 1999 season, only the crossbred lines were grown. The relative protein contents at each site again followed a similar general trend, but wet conditions at Ariah Park from mid-September to late October meant that the average grain protein content for the crossbreds was only $11 \%$. Thus, although the average grain protein contents 
Table 3. Mean grain properties and SDS-sedimentation of doubled haploid and crossbred lines, showing results for two seasons separately, and significance of difference between actual mean grain properties and SDS-sedimentation of doubled haploid and crossbred lines

\begin{tabular}{|c|c|c|c|c|c|c|}
\hline Site & Year & $\begin{array}{l}\text { Grain } \\
\text { protein } \\
(\%)\end{array}$ & $\begin{array}{l}\text { Yield } \\
(\mathrm{t} / \mathrm{ha})\end{array}$ & $\begin{array}{c}\text { Hectolitre } \\
\text { weight } \\
(\mathrm{kg})\end{array}$ & $\begin{array}{c}1000- \\
\text { kernel } \\
\text { weight }(\mathrm{g})\end{array}$ & $\begin{array}{l}\text { SDS-sed. } \\
\text { volume } \\
(\mathrm{mL})\end{array}$ \\
\hline & \multicolumn{6}{|c|}{ Hartog $\times C D 87^{A}$} \\
\hline \multirow[t]{2}{*}{ Ariah Park } & 1997 & 13.9 & - & 82.6 & 29.4 & 13 \\
\hline & 1998 & 12.6 & - & 83.8 & 39.3 & 11.9 \\
\hline \multirow[t]{2}{*}{ Narrabri } & 1997 & 13.2 & - & 82 & 39.3 & 10 \\
\hline & 1998 & 13.2 & - & 75.8 & 31.3 & 13 \\
\hline \multirow[t]{2}{*}{ Roma } & 1997 & 15.7 & - & 80 & 31.2 & 14.2 \\
\hline & 1998 & 14.1 & - & 77.7 & 36.4 & 11.4 \\
\hline \multirow[t]{3}{*}{ Walpeup } & 1997 & 17.2 & - & 73.6 & 21 & 14 \\
\hline & 1998 & 17.4 & - & 79.7 & 36.7 & 14.3 \\
\hline & \multicolumn{6}{|c|}{ Hartog $\times$ Klasic $^{B}$} \\
\hline \multirow[t]{2}{*}{ Ariah Park } & 1997 & 14.1 & - & 80.8 & 30.2 & 13.1 \\
\hline & 1998 & 13.1 & - & 83.4 & 44.9 & 12.9 \\
\hline \multirow[t]{2}{*}{ Narrabri } & 1997 & 13.4 & - & 82.5 & 42.5 & 10.1 \\
\hline & 1998 & 12.8 & - & 75.5 & 30 & 13.7 \\
\hline \multirow[t]{2}{*}{ Roma } & 1997 & 15.9 & - & 82.1 & 34 & 14.3 \\
\hline & 1998 & 13.8 & - & 77.5 & 35.2 & 12.1 \\
\hline \multirow[t]{3}{*}{ Walpeup } & 1997 & 16.3 & - & 68.3 & 20.6 & 14.2 \\
\hline & 1998 & 16.9 & - & 78 & 40.3 & 14.2 \\
\hline & \multicolumn{6}{|c|}{ Janz $\times \operatorname{Hartog}^{C}$} \\
\hline \multirow[t]{2}{*}{ Ariah Park } & 1998 & 13.3 & 4.5 & 83.4 & 43.7 & 9.5 \\
\hline & 1999 & 11 & 4 & 78.5 & 40.5 & 10 \\
\hline \multirow[t]{2}{*}{ Narrabri } & 1998 & 12.5 & - & 76.8 & 31.7 & 10.2 \\
\hline & 1999 & 12.9 & 10.2 & 80 & 39.2 & 10.9 \\
\hline \multirow[t]{2}{*}{ Roma } & 1998 & 13.9 & 3.3 & 77.9 & 35.8 & 9.6 \\
\hline & 1999 & 14 & 2.8 & 80.5 & 36.7 & 12.3 \\
\hline \multirow[t]{3}{*}{ Walpeup } & 1998 & 16.3 & 1 & 79.7 & 39.8 & 12.5 \\
\hline & 1999 & 15.8 & 1.5 & 74.3 & 27.3 & 14.1 \\
\hline & \multicolumn{6}{|c|}{ Janz2 $\times$ Dollarbird ${ }^{D}$} \\
\hline \multirow[t]{2}{*}{ Ariah Park } & 1998 & 12.8 & 4.9 & 84.5 & 43.9 & 9.5 \\
\hline & 1999 & 11 & 4.3 & 78.2 & 40.5 & 10.3 \\
\hline \multirow[t]{2}{*}{ Narrabri } & 1998 & 12.7 & - & 76.2 & 29.2 & 9.8 \\
\hline & 1999 & 12.9 & 9.8 & 78.5 & 37.1 & 11.1 \\
\hline \multirow[t]{2}{*}{ Roma } & 1998 & 13.8 & 3.4 & 77.9 & 31.7 & 9.9 \\
\hline & 1999 & 14.3 & 2.7 & 81.7 & 36.1 & 13.1 \\
\hline \multirow[t]{2}{*}{ Walpeup } & 1998 & 16.7 & 0.8 & 79.7 & 40.7 & 13.1 \\
\hline & 1999 & 15.5 & 1.4 & 77.3 & 29 & 14.3 \\
\hline \multirow[t]{2}{*}{ Average s.e.d. } & & 0.19 & 0.15 & 0.57 & 1.11 & 0.36 \\
\hline & \multicolumn{6}{|c|}{ Significance of difference (P values) } \\
\hline \multirow{2}{*}{\multicolumn{2}{|c|}{$\begin{array}{l}\text { Year.Cross } . \text { Narrabri } \times \text { Ariah Park } \\
\text { Year.Cross.Roma } \times \text { Walpeup }\end{array}$}} & $<0.001$ & 0.849 & 0.004 & $<0.001$ & 0.854 \\
\hline & & $<0.001$ & 0.69 & $<0.001$ & $<0.001$ & 0.092 \\
\hline
\end{tabular}

- , Not measured.

A 98 lines per site. ${ }^{\mathrm{B}} 101$ lines per site. ${ }^{\mathrm{C}} 36$ lines per site. ${ }^{\mathrm{D}} 14$ lines per site.

changed slightly between years, throughout the trial there was a close general relationship between contents achieved at Narrabri and Ariah Park. Roma provided intermediate protein contents and Walpeup the highest. This enabled direct comparison between the physical dough test results. The 2 sets of doubled haploid lines achieved similar protein contents, whereas the protein contents for the crossbred lines were slightly lower at some sites.

\section{Grain physical properties and flour extraction rate}

Hectolitre weight and 1000-kernel weight were assessed for each sample. Hectolitre weights above $74 \mathrm{~kg} / \mathrm{hL}$ are 
Table 4. Predicted mean grain properties and SDS-sedimentation of doubled haploid and crossbred lines, combining results for two seasons, and significance of difference between predicted means for grain properties and SDS-sedimentation of doubled haploid and crossbred lines (year as a random effect)

\begin{tabular}{|c|c|c|c|c|c|}
\hline Site & $\begin{array}{c}\text { Grain } \\
\text { protein } \\
(\%)\end{array}$ & $\begin{array}{l}\text { Yield } \\
(\mathrm{t} / \mathrm{ha})\end{array}$ & $\begin{array}{c}\text { Hectolitre } \\
\text { weight } \\
(\mathrm{kg})\end{array}$ & $\begin{array}{c}1000- \\
\text { kernel } \\
\text { weight }(\mathrm{g})\end{array}$ & $\begin{array}{l}\text { SDS-sed. } \\
\text { volume } \\
(\mathrm{mL})\end{array}$ \\
\hline \multicolumn{6}{|c|}{ Hartog $\times C D 87$} \\
\hline Ariah Park & 12.9 & - & 82.9 & 34.7 & 12.9 \\
\hline Narrabri & 12.9 & - & 78.7 & 35.8 & 11.9 \\
\hline Roma & 14.4 & - & 78.3 & 34.1 & 12.8 \\
\hline Walpeup & 17 & - & 76.3 & 29.2 & 14.6 \\
\hline \multicolumn{6}{|c|}{ Hartog $\times$ Klasic } \\
\hline Ariah Park & 13.3 & - & 81.7 & 37.9 & 13.5 \\
\hline Narrabri & 12.8 & - & 78.7 & 36.7 & 12.3 \\
\hline Roma & 14.3 & - & 78.9 & 34.4 & 13.3 \\
\hline Walpeup & 16.3 & - & 72.8 & 30.9 & 14.6 \\
\hline \multicolumn{6}{|c|}{ Janz $\times$ Hartog } \\
\hline Ariah Park & 12.5 & 4.2 & 81.1 & 40.5 & 9.6 \\
\hline Narrabri & 13.1 & 10.4 & 78.5 & 33.7 & 10.4 \\
\hline Roma & 14.4 & 3.1 & 79.4 & 34.7 & 10.7 \\
\hline Walpeup & 16.4 & 1.3 & 77.2 & 32 & 13.1 \\
\hline \multicolumn{6}{|c|}{ Janz $2 \times$ Dollarbird } \\
\hline Ariah Park & 12.3 & 4.6 & 81.6 & 40.6 & 9.7 \\
\hline Narrabri & 13.2 & 9.9 & 77.6 & 31.4 & 10.3 \\
\hline Roma & 14.4 & 3.1 & 80 & 32.3 & 11.3 \\
\hline Walpeup & 16.4 & 0.9 & 78.7 & 33.3 & 13.5 \\
\hline Average s.e.d. & 0.15 & 0.13 & 0.61 & 1.2 & 0.31 \\
\hline \multicolumn{6}{|c|}{ Significance of difference ( $P$ values) } \\
\hline $\begin{array}{l}\text { Narrabri (N) } v . \\
\text { Ariah Park (S) }\end{array}$ & $<0.001$ & $<0.001$ & 0.095 & $<0.001$ & $<0.001$ \\
\hline $\begin{array}{l}\text { Roma }(\mathrm{N}) v . \\
\text { Walpeup }(\mathrm{S})\end{array}$ & $<0.001$ & 0.040 & $<0.001$ & 0.013 & 0.005 \\
\hline
\end{tabular}

generally accepted suitable for prime hard wheat. With the exception of Walpeup in drought-stressed 1997, this was generally readily achieved. In fact, for several season $\times$ genotype set combinations, the Ariah Park samples actually provided the highest hectolitre weights. Grain size was generally acceptable ( $>30 \mathrm{~g} / 1000$ kernels), except for Walpeup in 1997, where it was significantly below this level due to a dry, short, sharp finish to the season, and 1999, when it was just below $30 \mathrm{~g}$ for a similar reason. Ariah Park also had a sharp finish in 1997 and the grain weights were again just below $30 \mathrm{~g}$. However, in the 1998 and 1999 seasons, grain weights were among the highest at Ariah Park. Narrabri grain weights were high in 1997 and 1999, but low in 1998. It was wet and warm during anthesis and initial grain filling, but drier during the pre-harvest period at Narrabri in 1998. Replicates were planted at Roma for the doubled haploid lines in the 1998 season, and the mean yield, grain protein content, grain size and density, and SDS-SV results were virtually identical (Table 1). Flour milling extraction rate was rather low $(<70 \%)$ in the small-grained
Walpeup samples from 1997, but quite acceptable for all other sites and seasons. In 1997, flour colour (Minolta L-b; Tables 5,6 ) was slightly poorer at the southern sites (means of 78.2-81.2) than at the northern sites (means of 80.1-81.2). In 1998, flour colours from the southern sites were either comparable with the northern sites (Hartog $\times$ CD 87 , Janz $\times$ Dollarbird) or were even significantly better (Hartog $\times$ Klasic and Janz $\times$ Hartog).

\section{SDS-Sedimentation volumes}

In 1997, the mean SDS-sedimentation volumes (SV) differed between the sites in the same direction as protein concentration increased (Table 3). Walpeup samples had higher grain protein contents than those from Roma but there were similar SV values for Hartog $\times$ CD87 between the sites. Interestingly, the protein content was only about $0.7-0.8 \%$ higher at Ariah Park than at Narrabri, but the SV values were significantly higher for both sets of doubled haploids. In 1998, grain protein contents for Narrabri and Ariah Park were reasonably close for each of the 4 sets of lines, and averaged about $13 \%$, and with Roma consistently higher by $1-1.5 \%$ protein. Despite this, the SDS-SV values from Ariah Park and Roma were similar for all of the 4 sets. Walpeup had the highest protein levels and the SDS-SV levels were also usually the highest in each set. In 1999, grain protein levels at Ariah Park were only 11\%, and the SDS-SV, which is affected by both total protein content and protein 'quality', was slightly lower. Walpeup had the highest protein levels and the highest SDS-SV. Taken together these results suggest that although the variation in average protein content affected the SDS-SV results, the protein of the grain from the southern sites was comparable with that of the 2 northern sites. Most commercial prime hard quality wheat wholemeals gave values of $9 \mathrm{~mL}$ or over (J. H. Skerritt and L. Hac, unpublished data). The mean values from all sample sets in this study were either comparable with, or exceeded this standard.

\section{Year as fixed or random effect}

The aim of the analysis treating year as a fixed effect (Table 3) was to determine whether the latitude contrast differences for each cross were consistent from year to year. Comparing Narrabri with Ariah Park, there were significant differences between these sites in individual years for grain protein, hectoliter weight, and 1000-kernel weight (Table 3), but the direction of the contrasts difference was not consistent for individual comparisons; for example, in one season the Narrabri samples for Hartog $\times$ CD87 had lower average protein than the Ariah Park ones and in the following season the Ariah Park ones were lower. Similarly, comparing Roma with Walpeup there were also significant differences between these sites in individual years for grain protein, hectoliter weight, and 1000-kernel weight (Table 3). 


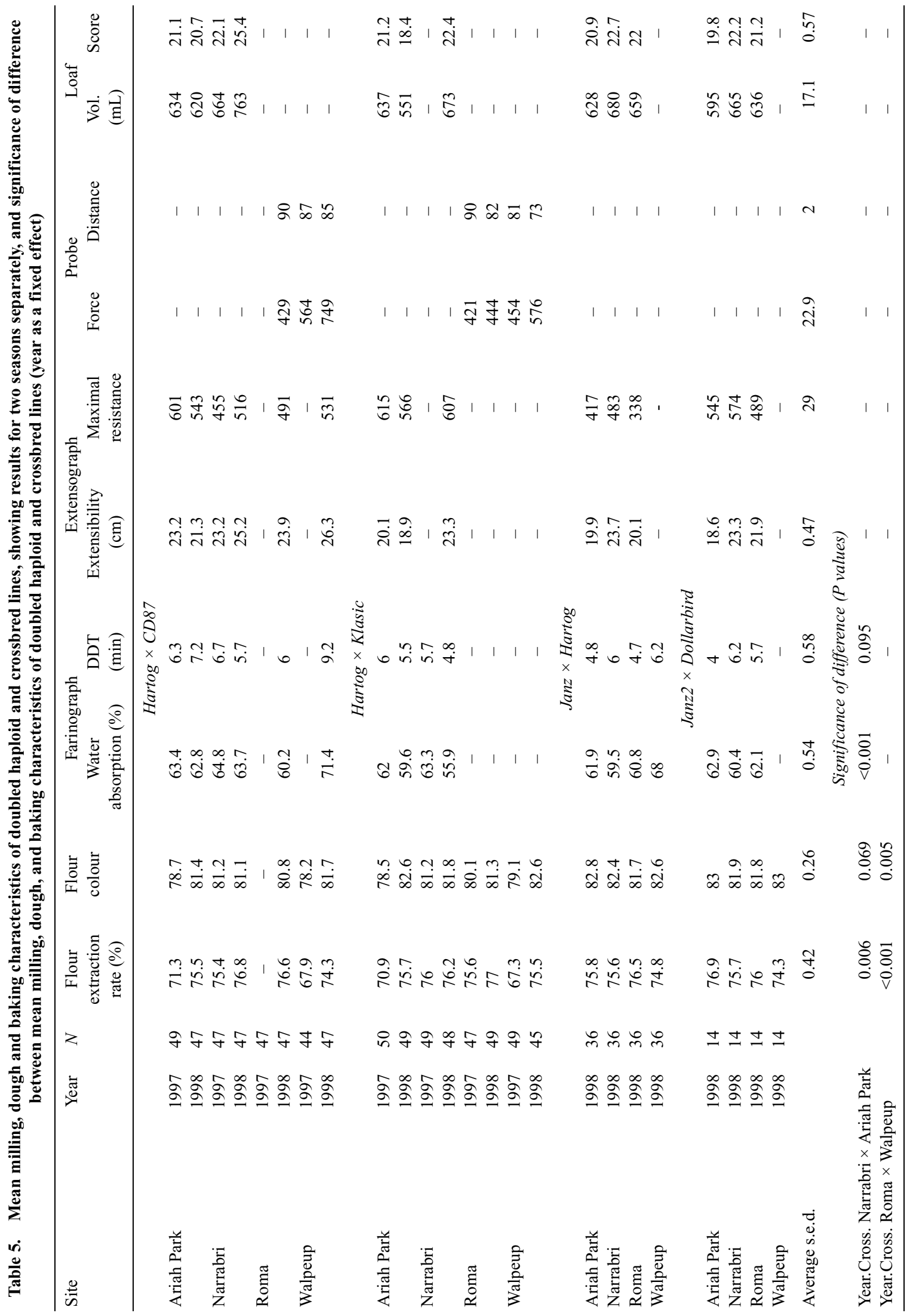


Table 6. Predicted mean milling, dough and baking characteristics of doubled haploid and crossbred lines, combining results for two seasons, and significance of difference between predicted mean milling, dough, and baking characteristics of doubled haploid and crossbred lines (year as a random effect)

\begin{tabular}{|c|c|c|c|c|c|c|c|c|c|c|}
\hline \multirow[t]{2}{*}{ Site } & \multirow{2}{*}{$\begin{array}{c}\text { Flour } \\
\text { extraction } \\
\text { rate }(\%)\end{array}$} & \multirow{2}{*}{$\begin{array}{l}\text { Flour } \\
\text { colour }\end{array}$} & \multicolumn{2}{|c|}{ Farinograph } & \multicolumn{2}{|c|}{ Extensograph } & \multicolumn{2}{|c|}{ Probe } & \multicolumn{2}{|c|}{ Loaf } \\
\hline & & & $\begin{array}{c}\text { Water } \\
\text { absorption (\%) }\end{array}$ & $\begin{array}{l}\text { DDT } \\
(\min )\end{array}$ & $\begin{array}{l}\text { Extensibility } \\
\qquad(\mathrm{cm})\end{array}$ & $\begin{array}{l}\text { Maximal } \\
\text { resistance }\end{array}$ & Force & Distance & $\begin{array}{l}\text { Vol. } \\
(\mathrm{mL})\end{array}$ & Score \\
\hline \multicolumn{11}{|c|}{ Hartog $\times C D 87$} \\
\hline Ariah Park & 73.4 & 80 & 63.1 & 6.7 & 22.2 & 573 & - & - & 627 & 20.9 \\
\hline Narrabri & 76.1 & 81.2 & 64.3 & 6.2 & 24.2 & 486 & - & - & 713 & 23.8 \\
\hline Roma & 74.7 & 79.8 & 61.7 & 6.1 & 24 & 494 & 377 & 93 & - & - \\
\hline Walpeup & 71.1 & 80 & 72.8 & 9.2 & 26.4 & 534 & 654 & 86 & - & - \\
\hline \multicolumn{11}{|c|}{ Hartog $\times$ Klasic } \\
\hline Ariah Park & 73.3 & 80.5 & 60.8 & 5.7 & 19.5 & 590 & - & - & 594 & 19.8 \\
\hline Narrabri & 76.1 & 81.5 & 59.6 & 5.3 & 23.4 & 609 & - & - & 673 & 22.4 \\
\hline Roma & 76.3 & 80.7 & - & - & - & - & 432 & 86 & - & - \\
\hline Walpeup & 71.3 & 80.8 & - & - & - & - & 514 & 77 & - & - \\
\hline \multicolumn{11}{|c|}{ Janz $\times$ Hartog } \\
\hline Ariah Park & 73.9 & 81.7 & 63.3 & 5 & 20 & 420 & - & - & 628 & 20.9 \\
\hline Narrabri & 73.7 & 81.3 & 60.9 & 6.1 & 23.8 & 486 & - & - & 680 & 22.7 \\
\hline Roma & 74.6 & 80.6 & 62.1 & 4.8 & 20.2 & 341 & - & - & 659 & 22 \\
\hline Walpeup & 72.9 & 81.5 & 69.4 & 6.3 & - & - & - & - & - & - \\
\hline \multicolumn{11}{|c|}{ Janz $2 \times$ Dollarbird } \\
\hline Ariah Park & 75 & 81.9 & 64.4 & 4.1 & 18.8 & 548 & - & - & 595 & 19.8 \\
\hline Narrabri & 73.8 & 80.8 & 61.9 & 6.3 & 23.4 & 577 & - & - & 666 & 22.2 \\
\hline Roma & 74.1 & 80.7 & 63.5 & 5.8 & 22.1 & 492 & - & - & 636 & 21.2 \\
\hline Walpeup & 72.4 & 81.9 & - & - & - & - & - & - & - & - \\
\hline Average s.e.d. & 0.51 & 0.31 & 0.61 & 0.59 & 0.51 & 29.8 & 19.1 & 1.7 & 19.4 & 0.65 \\
\hline \multicolumn{11}{|c|}{ Significance of difference (P values) } \\
\hline Cross. Narrabri $\times$ Ariah Park & $<0.001$ & $<0.001$ & $<0.001$ & 0.007 & $<0.001$ & $<0.001$ & - & - & 0.47 & 0.47 \\
\hline Cross. Roma $\times$ Walpeup & $<0.001$ & 0.033 & $<0.001$ & 0.016 & - & - & $<0.001$ & 0.589 & - & - \\
\hline
\end{tabular}

When sowing year was treated as a random effect (i.e. data for the same families for a given site were combined across years; Table 4) there was a significant interaction between the Narrabri-Ariah Park contrast and cross for all variables except hectolitre weight, showing that the magnitude of the contrast difference varied from cross to cross and at least one of these differences was statistically significant (Table 4). For example, grain protein was lower at Ariah Park than at Narrabri for Janz $2 \times$ Dollarbird and Janz $\times$ Hartog, but higher for Hartog $\times$ Klasic. Hectolitre weight was higher at Ariah Park for all crosses, whereas the quality parameter SDS-sedimentation volume was higher at Ariah Park for the 2 doubled haploid sets, but lower for the 2 cross-bred sets (where the grain protein content is also significantly lower; Table 4). There was a significant interaction between the Roma-Walpeup contrast and cross for all variables, showing that the magnitude of the contrast difference varied from cross to cross and at least one of these differences was statistically significant. For example, grain protein was higher at Walpeup than at Roma for all crosses, but the extent of the difference varied from cross to cross. Hectolitre weight was higher at Roma for all crosses, but the
SDS-sedimentation volumes were consistently higher at Walpeup, in keeping with the expected effect of higher grain protein content.

\section{Dough and baking properties}

In the 1997 samples, FWA valves were good $(>60 \%)$ for both sites tested (Narrabri and Ariah Park) and both sets of doubled haploid lines (Table 5). In the 1998 samples, acceptable FWA values were obtained at all sites for the CD87 $\times$ Hartog set and both sets of crossbreds, but they were low for the Hartog $\times$ Klasic set. In each case in 1998, the Ariah Park and Walpeup values were higher or at least equivalent to Roma and Narrabri. Farinograph DDTs were also typical of APH wheats; the lowest value obtained was 4 min, most values were in the 4.5-7 min range and the highest was $9 \mathrm{~min}$. With the doubled haploid lines, Narrabri was slightly higher than Ariah Park for 3 of the 4 comparisons. Walpeup in 1998 was higher for the 2 comparisons made. For Janz $\times$ Hartog and Janz2 $\times$ Dollarbird, Narrabri was lower than the other sites.

Extensograph maximal dough resistances were also typical for PH-type flours, exceeding $450 \mathrm{BU}$ for all of the 
doubled haploid means and for the Janz $2 \times$ Dollarbird lines; the Janz $\times$ Hartog doughs were slightly weaker (338-483 BU). Ariah Park and Narrabri were significantly higher than Roma for both sets of cross-breds, but with the doubled haploids there was not a consistent rank order. Probe testing was performed on flours from the doubled haploid lines grown at the higher protein sites (Roma (northern) and Walpeup (southern); Table 3, Fig. 2). In each pairwise comparison, the Walpeup site (which was $0.5-3.2 \%$ higher in protein on average) gave significantly greater probe force than the Roma site (analogous to Extensograph resistance), and slightly but significantly lower probe distance (analogous to Extensograph extensibility). In the 1998 season, when analyses of all 4 sets of lines were made, Ariah Park was consistently lowest in Extensibility (Table 5), which led to slightly but significantly lower loaf volumes and scores for this site. This was a reflection of the lower proteins for the site. In most cases it also had the lowest mean protein for this season. Baking and extensibility are known to be strongly correlated with protein content (Skerritt 1998). Unfortunately, flours from grain grown at the Walpeup site were not baked, because the low test weights and flour yields would lead to unreliable baking results.

\section{Year as fixed or random effect}

The Narrabri-Ariah Park contrast difference for each cross was consistent from year to year for flour colour and Farinograph DDT (Table 5), but not for flour extraction rate and FWA. There were insufficient data to calculate this contrast for all other variables. The Roma-Walpeup contrast difference for each cross was not consistent from year to year for flour extraction rate or flour colour. There were insufficient data to calculate this contrast for the physical dough tests and the bake tests. In analysis of year as a random effect (Table 6), there was a significant interaction between the Narrabri-Ariah Park contrast and cross for all milling analyses and all physical dough properties, showing that the magnitude of the contrast differences varied from cross to cross and at least one of these differences was statistically significant. For example, flour extraction rate was lower at Ariah Park for Hartog $\times$ CD87 and Hartog $\times$ Klasic, but higher for Janz $2 \times$ Dollarbird. The Narrabri-Ariah Park contrast and cross interaction were not significant for the bake tests, showing that the magnitudes of the contrast differences were consistent from cross to cross. For the bake tests, there were significant Narrabri-Ariah Park contrast effects, showing that the magnitude of the Narrabri-Ariah Park contrast difference was statistically significant. Extensograph extensibility was higher at Narrabri for all crosses, but the size of the difference varied from cross to cross. There was a significant interaction between the Roma-Walpeup contrast and cross for all milling analyses and all physical dough properties, except for probe distance, showing that the magnitude of the Roma-Walpeup contrast differences varied from cross to cross and at least one of these differences was statistically significant. For example, flour extraction rate was lower at Walpeup for all crosses, but the size of the difference varied from cross to cross.

\section{Allelic effects on quality parameters}

An analysis of the effects of different glutenin alleles and allelic combinations on dough processing quality was not the primary aim of this study. However, both the experimental design and the nature of the lines used in the study provided an excellent opportunity to do so. Firstly, each set of doubled haploid lines enabled comparison of several important alleles with a large number of independent lines of identical glutenin composition, for a wide range of grain properties, SDS-SV, dough testing, and baking properties. Each set of lines was grown at 4 quite different sites across 2 seasons, enabling the reliability of apparent relationships to be assessed across sites and seasons. Finally, at each site there was limited variation in grain protein level, enabling the confounding effects of protein variation to be avoided.

In the interests of brevity, only pair-wise comparisons of alleles are reported (Figs 1-3). Thus, epistatic or interactive effects between glutenin loci (Morel et al. 1994; Nieto-Taladriz et al. 1994) have not been reported. For most sites and seasons, there were no differences in protein content between the sets of lines grown at the same site and season but with contrasting glutenin allelic compositions. In a small number of cases ( 9 of 88 comparisons analysed) there was a slight, but just statistically significant difference, typically averaging $0.4 \%$ protein content. The lack of major differences in protein contents between the sets means that allele-quality relationships are studied without the complicating effect of variation in grain protein within environments. Similarly, with only 1-2 exceptions in each set of 88 comparisons, there were no differences in grain yield, 1000-kernel weight, or hectolitre weight between any of the allele pairs. Similarly, although water absorption, flour colour, and loaf colour are critical quality characteristics, they were not affected by glutenin allelic composition. A number of consistent differences were noted between allelic pairs for dough rheological parameters; where differences were noted for one site $\times$ season combination, they were typically noted for others. Exceptions are discussed below.

\section{High molecular weight glutenin subunits $\left(H M_{r}-G S\right)$}

Relationships between quality parameters and $G l u-A 1$ alleles $\mathrm{a}$ and $\mathrm{b}$ ( $\mathrm{HM}_{\mathrm{r}} \mathrm{GS}$ subunits 1 and $2 *$, respectively) were analysed in the Hartog $\times$ CD87 set (Figs $1 a-d, f, 2)$. There were no significant effects on SDS-SV, Rmax, Extensibility, Farinograph DDT (except for Ariah Park in 1997), loaf volumes, or probe force. This is in keeping with earlier studies, which have shown that subunits 1 and $2 *$ provide consistently higher dough strength parameters than the null 
allele at this locus, but are similar in their effects to one another (Moonen et al. 1983; Halford et al. 1992). Branlard and Dardevet (1985) also obtained higher values of Alveograph strength and SDS sedimentation in lines with 1 and $2 *$ compared with the null locus. The 2 subunits also have the same Payne quality scores (Payne et al. 1987). Effects of Glu-B1 alleles b and i (HM $\mathrm{rSS}$ subunits $7+8$ and $17+18)$ were analysed in both the Hartog $\times$ CD87 doubled haploid population (Figs $1 a-d, f, 2$ ) and the Janz $\times$ Hartog crossbred population (Fig. 3). In the doubled haploid population, the effects of allelic variation were typically greater, with the $\mathrm{b}$ allele being significantly higher in SDS-SV for each of the possible 8 site $\times$ season combinations (Fig. 1a). In contrast, the trend was for the $\mathrm{i}$ allele to give higher SDS-SV values in the cross-breds (Fig. 3a), although this only reached statistical significance in 3 of 8 comparisons. Results with maximal dough resistance provided similar trends to those for Rmax, which is not surprising given that both are dependent on the quantity of large glutenin polymers in the flour. With the doubled haploid lines, the $\mathrm{b}$ allele provided higher dough resistance values for all 8 site/season combinations (Fig. 1b), whereas opposite trends were seen with the crossbreds (Fig. $3 b$ ), although only one site (Ariah Park 1998) achieved statistical significance. Dough extensibility also was greater for the $\mathrm{b}$ allele in the doubled haploids (Fig. 1c), reaching statistical significance in 4 of the 6 combinations. Again, the opposite trend was noted with the crossbreds (data not shown), although this only achieved statistical significance in onecase. Probe testing of the flour samples from Roma and Walpeup was performed instead of Extensograph testing due to the high protein contents. For each year and site studied, the $\mathrm{b}$ allele gave higher force (analogous to dough resistance), whereas the distance (analogous to extensibility) was typically similar for both alleles (Fig. 2), only being higher for Roma in the 1998 season.

Farinograph DDT in the doubled haploids was greater for the $\mathrm{b}$ allele that the $\mathrm{i}$ allele, achieving statistical significance in 4 of the 6 sets analysed (Fig. 1d). No differences between the $\mathrm{b}$ and $\mathrm{i}$ alleles were noted in the cross-breds (Fig. 3c). Loaf volumes were analysed for Narrabri and Ariah Park (Fig. 1f). They were generally unaffected by allelic composition, being slightly lower for the $\mathrm{b}$ allele at Ariah Park in 1997 only. Few other studies have systematically compared the effects of the Glu-B1b and Glu-B1i alleles on quality parameters. Where such studies have done so (Payne et al. 1987; MacRitchie et al. 1990), the alleles have been reported to have similar effects on dough properties.

The effects of Glu-D1 alleles a and d (HMW-GS subunits $2+12$ and $5+10$, respectively) were analysed in the Hartog $\times$ CD87 population and in both sets of the crossbred lines. In the Hartog $\times$ CD87 population, measures of dough strength (Rmax) (Fig. 1b) and probe force (Fig. 2) as well as Farinograph DDT (Fig. 1d) were significantly higher for the $\mathrm{d}$ allele for all sites and seasons. In the cross-breds there was a larger but consistent difference in Rmax between the a and $\mathrm{d}$ alleles at each site (Fig. $3 b$ ). Similar trends were seen in the Janz2 $\times$ Dollarbird sets, although they failed to achieve statistical significance. Farinograph DDT was greater for the $d$ allele than the a allele in 5 of 6 sets of the Hartog $\times$ CD87 doubled haploids (Fig. 1d) and in all sites studies for the Janz $\times$ Hartog crossbreds (Fig. 3c). There was, however, no difference with the Janz $2 \times$ Dollarbird crossbreds.

Although a large number of other published studies had demonstrated consisted differences (Burnouf and Bouriquet 1980; Payne et al. 1981), SDS-SV values (Fig. 1a) were not usually significantly different between the sets, except in 3 cases (Janz $\times$ Hartog at Ariah Park 1998, Janz $\times$ Dollarbird at Ariah Park 1999, and Walpeup 1998). There was a trend for the d allele to be associated with lower extensibilities than the a allele, although this only achieved statistical significance in about half of the doubled haploid sites $\times$ seasons, and in none of the cross-bred experiments (data not presented). Similar effects on extensibility have been observed before (Gupta et al. 1992; Morel et al. 1994). Loaf volumes were assessed for Narrabri and Ariah Park (1997 and 1998) for the Hartog $\times$ CD87 population (Fig. 1f), and Narrabri, Ariah Park, and Roma (1998) for the cross-breds (data not shown). Alleleic differences were not marked, and where there was a difference, the d allele was lower (Hartog $\times$ CD 87 at Ariah Park in 1997 and 1998, Janz $\times$ Hartog at Ariah Park in 1998). The equivocal effects of the Glu-D1d allele on loaf volume in the face of clear effects on dough strength have been noted earlier (MacRitchie et al. 1990; Skerritt 1998).

\section{Low molecular weight glutenin subunits (LMrGS)}

In general, the differences in dough properties, SDS-SV, and loaf volumes between the sets of lines with differing $\mathrm{LM}_{\mathrm{r}} \mathrm{GS}$ alleles were less marked than for the differing $\mathrm{HM}_{\mathrm{r}} \mathrm{GS}$ alleles in keeping with earlier studies (Gupta and Shepherd 1988; Gupta et al. 1994). The Glu-A3b and Glu-A3d alleles were compared in the Hartog $\times$ Klasic population. There were inconsistent effects on SDS-SV, with usually little difference between the alleles, although in one case, b was significantly lower (Walpeup 1997) and in another case higher (Ariah Park 1998, data not presented). There was no apparent effect of Glu-A3 alleic composition on Rmax, probe force or distance, or loaf volumes. The only other published comparison of the effects of these alleles suggested that the $b$ allele was associated with greater Extensograph resistance, but this was a correlative study with a broad range of genotypes rather than a genetic study (Gupta et al. 1991). Farinographs were produced for Narrabri and Ariah Park in 1997 and 1998. The trend for the alleic comparisons for all 4 site $\times$ season combinations were for $b$ to be greater than $d$; this was statistically significant when the data were aggregated, but just outside statistical significance $(P=0.055-0.065)$ when each site and season 

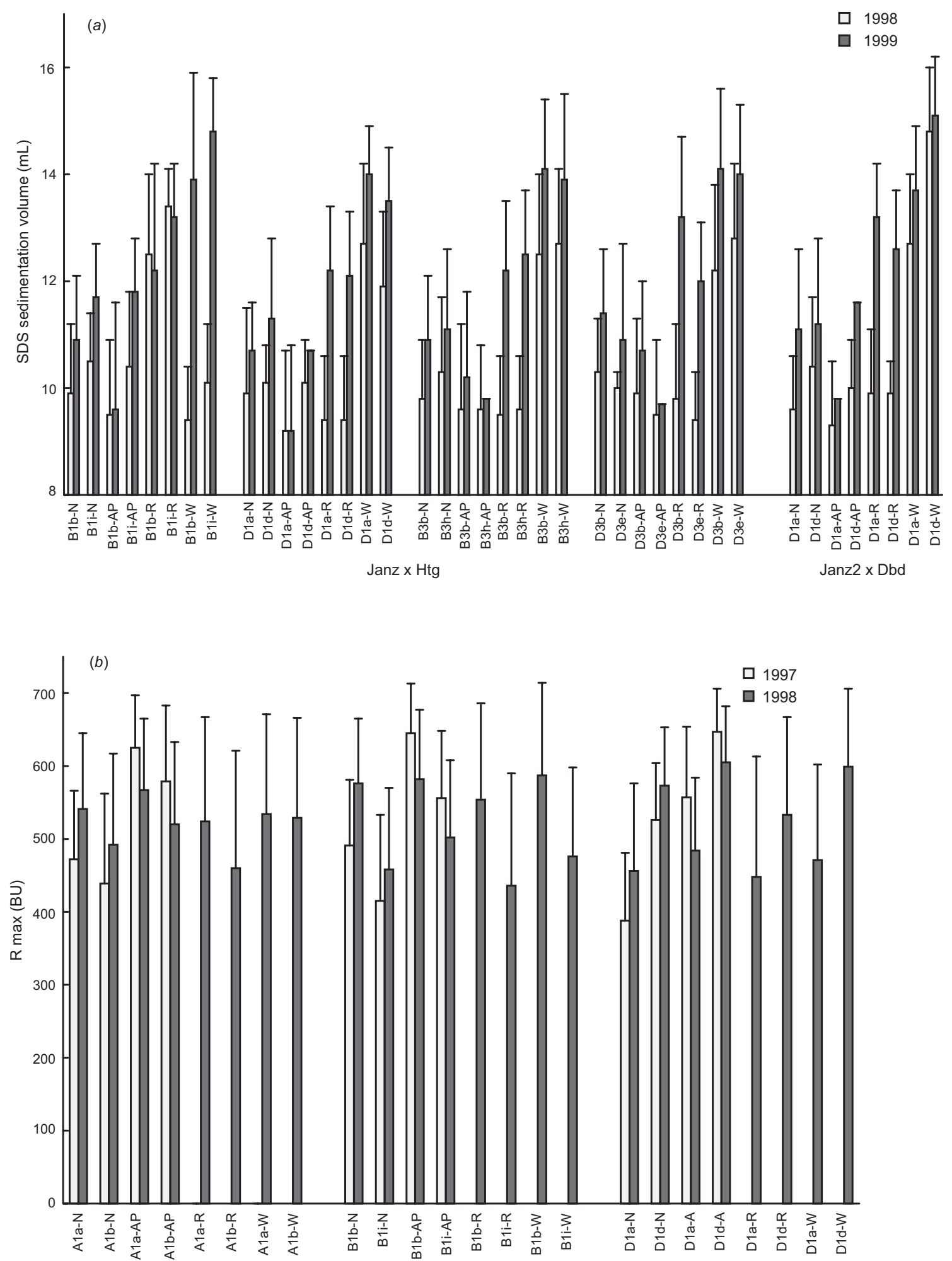

Fig. 1. Effect of glutenin subunit alleles in doubled haploid lines on selected quality characteristics at each site: $(a) \mathrm{HM}_{\mathrm{r}} \mathrm{GS}$ and SDS-sedimentation volume, $(b) \mathrm{HM}_{\mathrm{r}} \mathrm{GS}$ and Extensograph maximal dough resistance. Legend indicates allele and site, e.g. $A 1 a-R$ $=G l u-A 1$ ' $\mathrm{a}$ ' allele (HM,GS-1) at Roma. For the doubled haploid lines, comparisons at Glu-A1, Glu-B1, Glu-D1, Glu-B3, and Glu-D3 are from the Hartog $\times$ CD-87 population, whereas Glu-A3 comparisons are from the Hartog $\times$ Klasic population. (Continued next page.) 

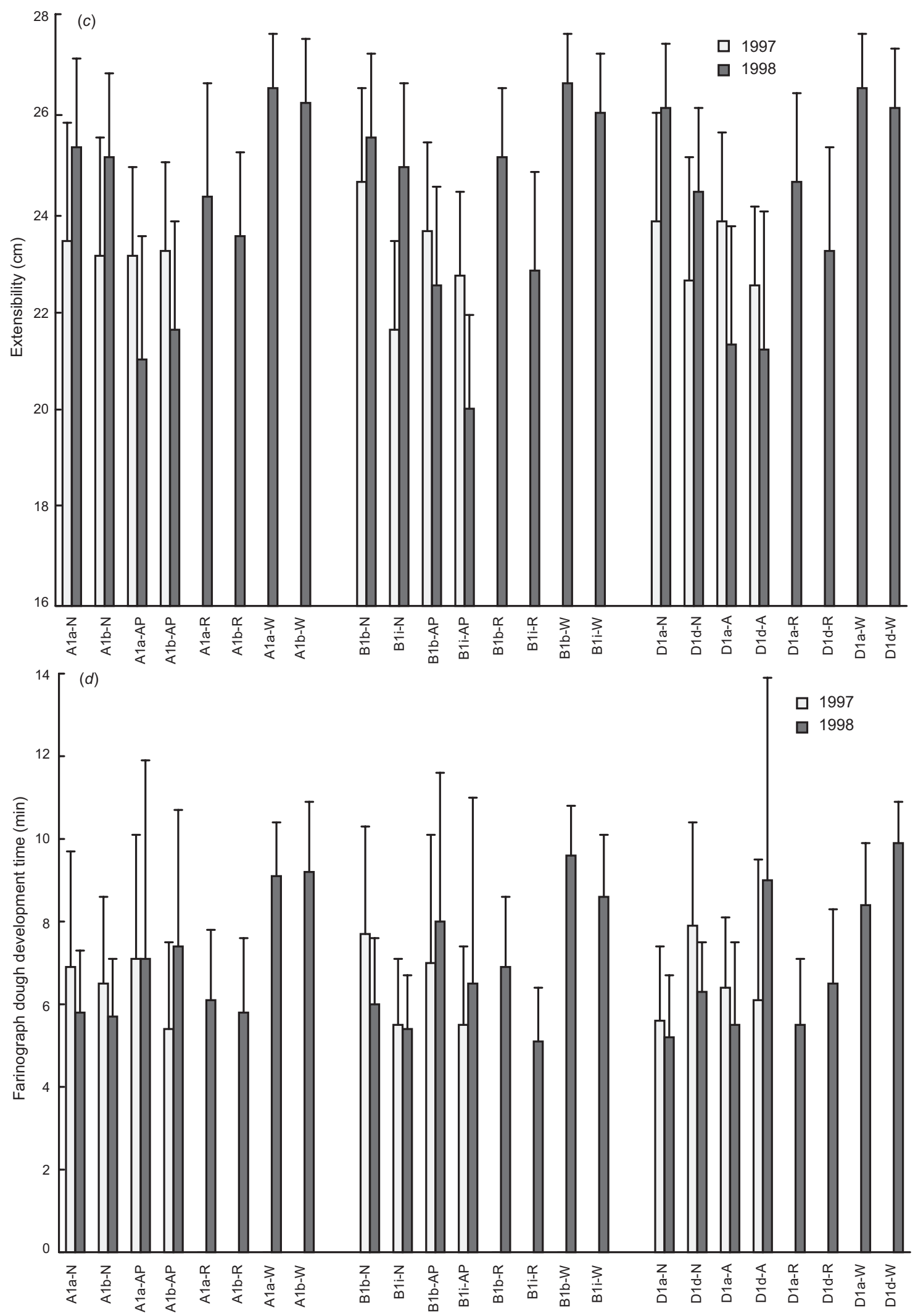

Fig. 1. (Contd) (c) $\mathrm{HM}_{\mathrm{r}} \mathrm{GS}$ and Extensograph extensibility, $($ d $) \mathrm{HM}_{\mathrm{r}} \mathrm{GS}$ and Farinograph dough development time. (Continued next page.) 

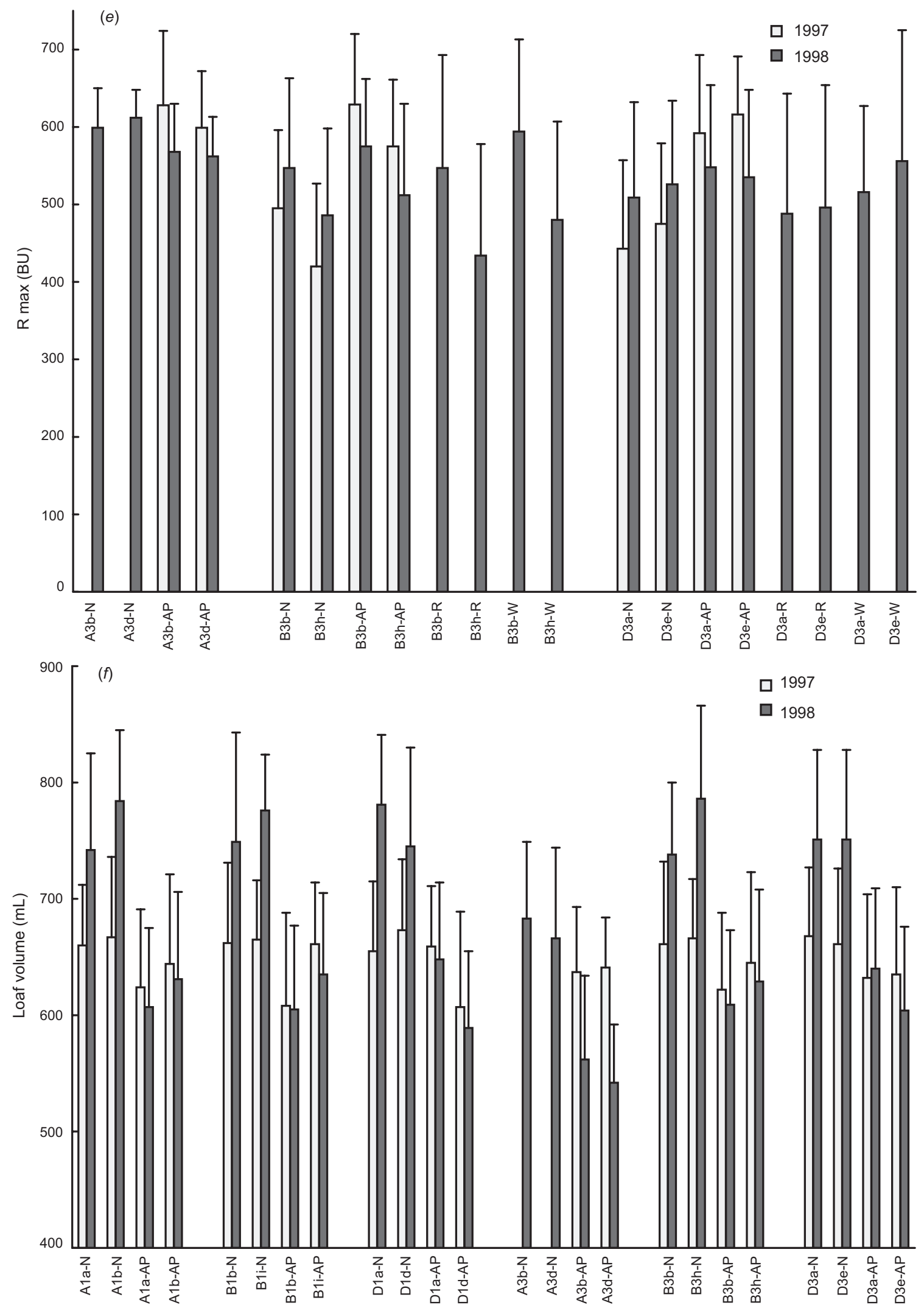

Fig. 1. (Contd) (e) $\mathrm{LM}_{\mathrm{r}} \mathrm{GS}$ and Extensograph maximal dough resistance, and $(f) \mathrm{HM}_{\mathrm{r}} \mathrm{GS}$ and $\mathrm{LM}_{\mathrm{r}} \mathrm{GS}$ and loaf volumes. 


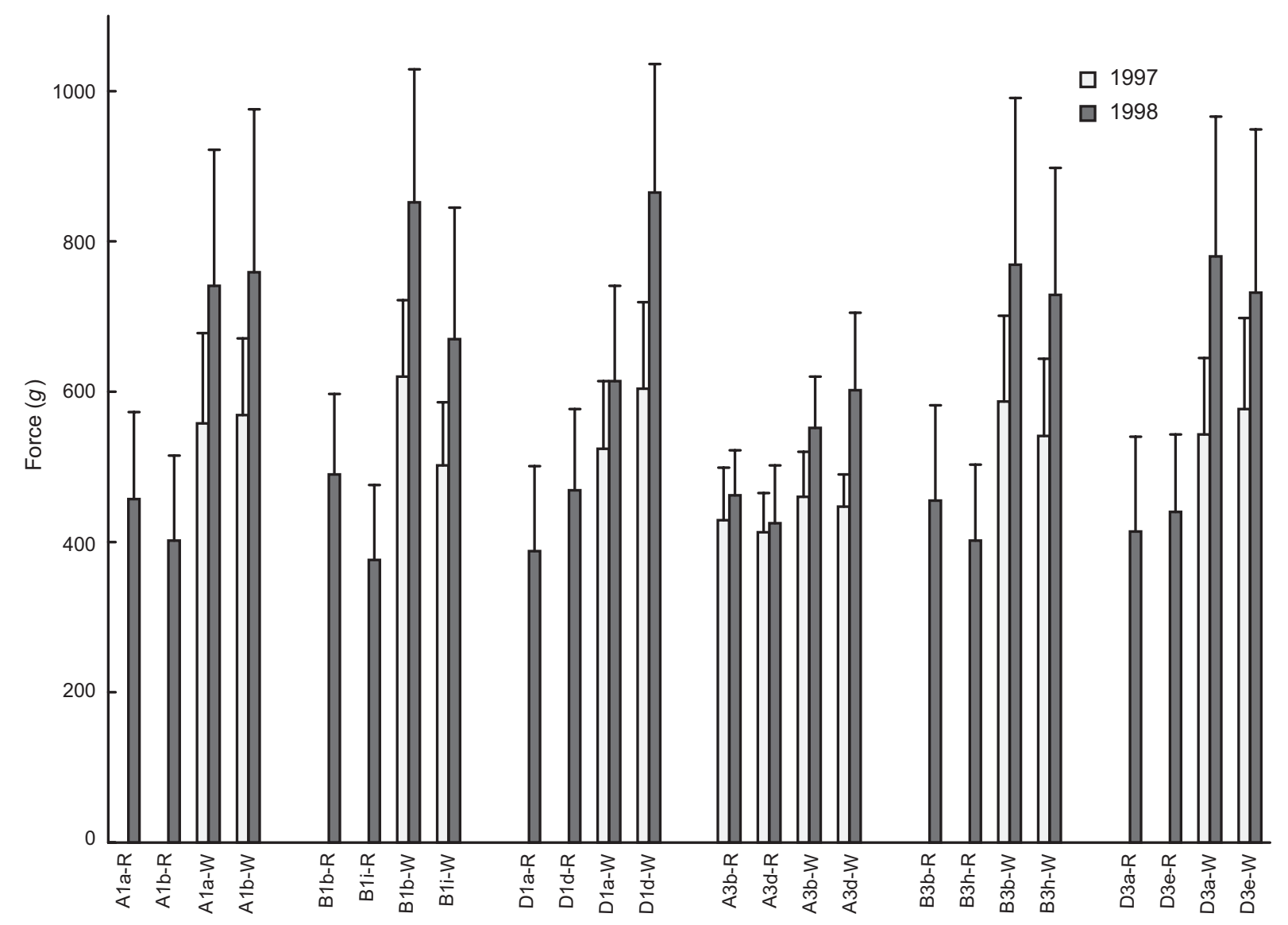

Fig. 2. Effects of glutenin subunit alleles at high flour protein contents; probe force in doubled haploid lines grown at Roma and Walpeup.

was analysed separately. The Glu-A3 alleic difference was the only difference in glutenin composition between individual Hartog $\times$ Klasic lines, but there was nonetheless a large range in SDS-SV, dough and baking properties within the sets of doubled haploids derived from these parents. The range was comparable with the Hartog $\times$ CD87 lines (Tables 2,3). This result demonstrates that factors other than variation in glutenin composition also play a role in determining processing quality.

Glu-B3 alleles b and h were compared in both the Hartog $\times$ CD87 and the Janz $\times$ Hartog populations. With the doubled haploids, maximal dough resistance was greater for the $b$ allele for all 6 sites $\times$ season combinations (Fig. 1e). Similar trends were noted for the crossbreds but they did not reach statistical significance (Fig. 3b). There were no differences in the probe testing results or SDS-SV values, although an earlier comparison of lines from a cross, correlated the $b$ allele with higher values (Shahriari et al. 1994). There were no differences in Extensibility or Farinograph DDT for the doubled haploids, but there was a trend for the $\mathrm{b}$ allele to be greater than the $\mathrm{h}$ allele for Janz $\times$ Hartog; this was significant for the 2 southern sites in the only season tested (data not presented). Similarly, there were few differences in loaf volume data, but the b allele was lower in 1998 for Narrabri.

Glu-D3 alleles a and e were compared in the Hartog $\times$ CD87 population (Fig. 1e,f) and Glu-D3 alleles b and e in the Janz $\times$ Hartog crossbreds (Fig. $3 a-c$ ). There were no significant differences in SDS-SV, or in any of the dough or baking parameters at any of the sites or seasons, with the exception of Farinograph DDT at Ariah Park in 1997 for the cross-bred set. Shahriari et al. 1994 also failed to detect differences in SDS-SV between progeny of a cross with the c and e alleles, whereas the rankings of Gupta et al. (1991) ranked cultivars with the e allele higher in extensibility than cultivars with the c allele.

\section{Conclusions}

The northern control sites (Narrabri and Roma) had 13-16\% and $15-17 \%$ grain protein, respectively, and the southern sites also averaged similar protein levels, but through late $\mathrm{N}$ application (Ariah Park) and drought (Walpeup), respectively. In general, the flours from the Ariah Park southern site had dough strength properties (i.e. SDS-sedimentation volumes, Extensograph maximal resistance, and Farinograph development times) similar to 

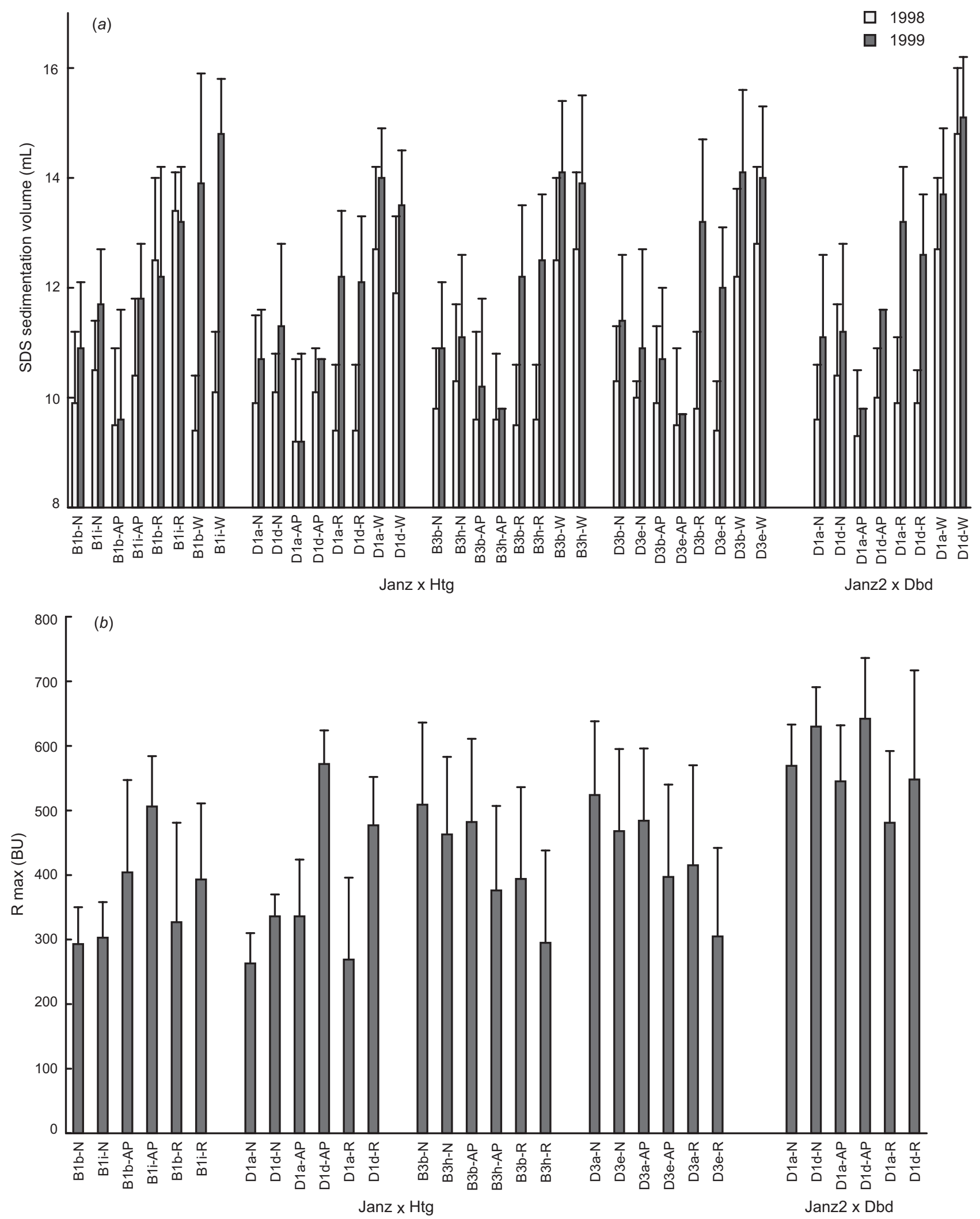

Fig. 3. Analysis of influences of glutenin subunit alleles in crossbred lines: (a) SDS-sedimentation volume, $(b)$ Extensograph maximal dough resistance, and $(c)$ Farinograph dough development time. 
the northern sites, and the highest protein Walpeup southern site often had the strongest doughs. Samples from the Ariah Park site had lower extensibilities and loaf volumes in the 1998 season. Both these parameters were measured for each set of lines, as both measurements are directly related to protein content and this can be explained by the lower protein contents that were obtained at Ariah Park that season. Milling extraction rate and flour colour may be main criteria on which the grain from low rainfall southern sites could sometimes 'fail' to achieve APH standard. Dry growing seasons often have a greater effect than $\mathrm{N}$ fertiliser on grain protein content (Lopez-Bellido et al. 1998). In the dry 1997 season, grain from the Walpeup site was low in size, and provided poorer milling extraction rates and flour colour. Small grain size, especially in droughted high-protein samples from southern NSW, were also found by Allen and Pumpa (1999) in a study of 4 varieties grown at several sites. In 'haying off', which is premature ripening during significant terminal drought, additional $\mathrm{N}$ inputs can decrease kernel weights and at the same time increase grain protein (van Herwaarden et al. 1998). Taken together, the results suggest that in many seasons, grain of APH quality can be grown at southern sites, although economic factors such as the cost of nitrogen fertiliser and the potential premiums for prime hard wheats compared with other grades are obviously important.

Although the primary focus of this study was on the effects of growth environment on dough parameters of these high-protein wheats, the experimental design also enabled a careful analysis of influences of glutenin allelic composition on dough and baking properties. Most of the earlier analyses of this type have either been based on correlative studies with sets of varieties, comparisons of biotypes, or analysis of the progeny of one or more crosses. Only very few studies done in this manner have also grown the material in several environments to show that the trends obtained are indeed consistent. The establishment of reliable techniques for the development of doubled haploid populations provides a simple alternative for obtaining populations of lines with fixed backgrounds. It is likely that some of the major advances in associating grain protein composition with dough properties will derive from analysis of doubled haploid populations. Nonetheless, this approach still only enables comparison of a pair of alleles at each locus.

In the present study, major influences on a number of dough properties of allelic variation at Glu-B1 and Glu-D1 were observed, along with minor influences of other loci, including Glu-B3. The Glu-3 loci, which encode both $\mathrm{LM}_{\mathrm{r}} \mathrm{GS}$, and the gliadin Gli-1 locus, are usually tightly linked (Singh and Shepherd 1988) so effects may be due to the monomeric gliadins, although this is less likely (Skerritt 1998). The Glu-D1 results are consistent with results of a number of earlier studies (e.g. Payne et al. 1987), although we found the influences of the Glu-B1 allelic variation often to be greater. In general, differences between dough properties in lines with differing allelic composition were greater with the doubled haploid sets than with the crossbreds, and the genetic background was very important, as contrasting results of potential effects of Glu-B1 allelic comparisons at the same locus were sometimes seen in the doubled haploids and the crossbreds.

\section{Acknowledgments}

The authors are grateful for the efforts of several others who assisted in this work: Greg Naglis and Luch Hac (CSIRO Plant Industry, Canberra), Neil Vallance (Victorian Institute of Dryland Agriculture, Walpeup), Phil Banks and Paul Brennan (Qld Department of Primary Industries Leslie Centre, Toowoomba), Jen Pumpa (NSW Agriculture, Wagga Wagga), and Christine Donnelly and Ann Cowling (Australian National University). The advice and encouragement of Dr Colin Wrigley and Mr John Oliver (Value Added Wheat CRC) are especially acknowledged.

\section{References}

Allen HM, Angus JF, Oliver JR, Apps JK (1998) High quality, high protein wheat in Southern Australia. In 'Proceedings 48th Australian Cereal Chemistry Conference, Cairns Queensland'. (Eds L O'Brien, AB Blakeney, AS Ross, CW Wrigley) pp. 171-174. (Royal Australian Chemical Institute: Melbourne)

Allen HM, Pumpa JK (1999) High quality, high protein wheat in Southern Australia. In 'Cereals '99. Proceedings of the 49th Australian Cereal Chemistry Conference'. (Eds J Panozzo, M Ratcliffe, M Wootton, CW Wrigley) pp. 129-135. (Royal Australian Chemical Institute: Melbourne)

Bhandari DG (2000) The early prediction of breadmaking quality of grain and its improvement through targeted late application of nitrogen fertilizers. HGCA Project Peport No. 219. pp 37, Home Grown Cereals Authority, London.

Branlard G, Dardevet M (1985) Diversity of grain protein and bread wheat quality. II. Correlation between high molecular weight subunits of glutenin and flour quality characteristics. Journal of Cereal Science 3, 345-354.

Burnouf T, Bouriquet R (1980) Glutenin subunits of genetically-related European hexaploid wheat cultivars: their relation to breadmaking quality. Theoretical and Applied Genetics 58, 107-111.

Gupta RB, Batey IL, MacRitchie F (1992) Relationships between protein composition and functional properties of wheat flours. Cereal Chemistry 69, 125-131.

Gupta RB, Bekes F, Wrigley CW (1991) Prediction of physical dough properties from glutenin subunit composition in bread wheats: correlation study. Cereal Chemistry 68, 328-333.

Gupta RB, Paul JG, Bekes F, Cornish G, Rathjen AJ (1994) Allelic variation in glutenin subunit and gliadin loci, Glu-1, Glu-3 and Gli-1 of common wheats. I. Its additive and interaction effects on dough properties. Journal of Cereal Science 19, 9-17.

Gupta RB, Shepherd KW (1988) Low molecular weight glutenin subunits in wheat: their variation, inheritance and association with breadmaking quality. In 'Proceedings of the 7th International Wheat Genetics Symposium'. pp 943-949. (Institute of Plant Science Research: Cambridge, UK)

Halford NG, Field JM, Blair H, Urwin P, Moore K, Robert L, Thompson R, Flavell RB, Tatham AS, Shewry PR (1992) Analysis of HMW subunits encoded by chromosome $1 \mathrm{~A}$ of bread wheat 
(Triticum aestivum L.) indicates quantitative effects on grain quality. Theoretical and Applied Genetics 83, 373-378.

van Herwaarden AF, Farquhar GD, Angus JF, Richards RA, Howe GN (1998) 'Haying off'. The negative grain yield response of dryland wheat to nitrogen fertiliser. I. Biomass, grain yield, and water use. Australian Journal of Agricultural Research 49, 1067-1081.

Lopez-Bellido L, Fuentes M, Castillo JE, Lopez-Garrido FJ (1998) Effects of tillage, crop rotation and nitrogen fertilization on wheat quality grown under rainfed Mediterranean conditions. Field Crops Research 57, 265-276.

MacRitchie F, duCros DL, Wrigley CW (1990) Flour polypeptides related to wheat quality. Advances in Cereal Science and Technology 10, 79-145.

Moonen JHE, Scheepstra A, Graveland A (1983) The positive effects of the high molecular weight glutenin subunits $3+10$ and $2^{*}$ of glutenin on the breadmaking quality of wheat cultivars. Euphytica 32, $735-742$.

Morel MH, Bonicel J, Melas V, Autran JC (1994) Multiple approach (IEF, SDS-PAGE and A-PAGE) on the composition of LMW subunits and its effect on dough properties. In 'Gluten proteins 1993’. pp. 244-254. (Association of Cereal Research, Detmold, Germany)

Neuhoff V, Arold N, Taube D, Ehrhardt W (1988) Improved staining of proteins in polyacrylamide gels including isoelectric focusing gels with clear background at nanogram sensitivity using Coomassie Brilliant Blue G-250 and R-250. Electrophoresis 9, 255-262.

Nieto-Taladriz MT, Perretant MR, Rousset M (1994) Effect of gliadins and HMW and LMW subunits of glutenin on dough properties in the F6 recombinant inbred lines from a bread wheat cross. Theoretical and Applied Genetics 88, 81-88.

Oliver JR, Allen HM (1993) Measurement of dough strength. In 'Proceedings of the 43rd Australian Cereal Chemistry Conference'. (Ed. CW Wrigley) pp. 128-131. (Royal Australian Chemical Institute: Melbourne)

Oliver J, Angus J, Anderson W, Birchel C, Butler G, Doyle D, Fettell N, Good T, McCormack P, Mullen C, Reimers H, Saunders R, Trethowan R, Vallance N (1997) High quality, high protein wheat in southern Australia. In 'Cereals '97. Proceedings of the 47th Australian Cereal Chemistry Conference'. (Eds AW Tarr, AS Ross, CW Wrigley) pp. 32-36. (Royal Australian Chemical Institute: Melbourne)

Oliver J, Angus J, Blackman J, Callaghan G, Cole C, Doyle D, Fettell N, Feruglio S, Good T, McCormack P, McDonald G, McKenzie E, Mullen C, Parker P, Pitson G, Saunders R, Skerritt J, Trethowan R, Vallance N (1996). High protein, high quality wheat in southern Australia. In 'Gluten' 96, Proc. Sixth Int. Gluten Workshop. (Ed. CW Wrigley) pp. 29-35. (Royal Australian Chemical Institute: Melbourne)
Oliver JR, Blakeney AB, Allen HM (1992) Measurement of flour color in color space parameters. Cereal Chemistry 69, 546-552.

Payne PI, Corfield KG, Holt LM, Blackman JA (1981) Correlations between the inheritance of certain high-molecular weight subunits of glutenin and breadmaking quality in progenies of six crosses of bread wheat. Journal of the Science of Food and Agriculture 32, $51-60$.

Payne PI, Nightingale MA, Krattiger AF, Holt LM (1987) The relationship between the HMW glutenin subunit composition and the breadmaking quality of British-grown wheat varieties. Journal of the Science of Food and Agriculture 40, 51-65.

Pena RJ, Amaya A, Rajaram S, Mujeeb-Kazi A (1990) Variation in quality characteristics associated with some spring $1 \mathrm{~B} / 1 \mathrm{R}$ translocation wheats. Journal of Cereal Science 12, 105-112.

Royal Australian Chemical Institute, Cereal Chemistry Division (1988) Official testing methods (Ed. T Westcott) (RACI: Parkville, Vic.)

Shahriari F, Rathjen AJ, Shepherd KW (1994) Contributions of Glu-1 and Glu-3 loci to dough strength as measured by SDS-sedimentation tests. In 'Proceedings of the 44th Australian Cereal Chemistry Conference'. (Ed. CW Wrigley) pp. 291-295. (Royal Australian Chemical Institute: Melbourne)

Singh NK, Shepherd KW (1988) Linkage mapping of genes controlling endosperm storage proteins in wheat. 1. Genes on the short arms of group 1 chromosomes. Theoretical and Applied Genetics 75, 628-641.

Singh NK, Shepherd KW, Cornish GB (1991) A simplified SDS-PAGE procedure for separating LMW subunits of glutenin. Journal of Cereal Science 14, 203-208.

Skerritt JH (1998) Gluten proteins: genetics, structure and dough quality. AgBiotech News and Information 10, 247N-270N.

Woodard HJ, Bly A (1998) Relationship of nitrogen management to winter wheat yield and grain protein in South Dakota. Journal of Plant Nutrition 21, 217-233.

Wrigley CW, Baxter RI (1974). Identification of Australian wheat cultivars by laboratory procedures: grain samples containing a mixture of cultivars. Australian Journal of Experimental Agriculture and Animal Husbandary 14, 805-810.

Manuscript received 17 December 2001, accepted 7 August 2003 